\title{
Effect of hyaluronic acid on skin healing in diabetic rats
}

\section{Efeito do ácido hialurônico na cicatrização da pele em ratos diabéticos}

Ariadne Sibelle Varela Constantino de Medeiros ${ }^{1}$, Lívia Medeiros Soares Celani ${ }^{2}$, Aldo Cunha Medeiros ${ }^{3}$.

1. Graduate student, Medical School, Federal University of Rio Grande do Norte (UFRN), Natal-RN, Brazil.

2. Fellow Master degree, Postgraduate Program in Health Sciences, UFRN, Natal- RN, Brazil

3. PhD, Full Professor, Chairman, Nucleus of Experimental Surgery, UFRN, Natal-RN, Brazil.

Work performed at the Department of Surgery, Federal University of Rio Grande do Norte (UFRN), Brazil.

Financial Support: CNPq.

Conflict of interest: None.

Mailing Address: Department of Surgery, Federal University of Rio Grande do Norte, Av. Nilo Peçanha 620, Natal, RN, Brazil. Email: cirurgex.ufrn@gmail.com

Submitted: september 19; accepted after revision, september 22, 2019.

\section{ABSTRACT}

Purpose: The objective of this study was to examine the effect of topical hyaluronic acid (HA) treatment on wound healing in diabetic rats. Methods: Wistar rats weighing $279 \pm$ $32 \mathrm{~g}$ were randomly selected and allocated into 2 groups, with six rats each, all submitted to diabetes induction with streptozotocin. Under anesthesia, a $1 \mathrm{~cm} 2$ open wound was made on the back skin of all animals. Group 1 - rats treated with topical $0.9 \%$ saline use on open skin wounds. Group 2 - rats treated with topical use of $0.4 \%$ HA over skin lesions. After anesthesia on the 10th postoperative day, a biopsy of the skin dorsal wound area, including the entire healing wound, was performed for histopathological examination. Quantitative analysis was performed for the amount of macrophages, vascular neoformation, fibroblasts and collagen fibers, using a digitizer and image analyzer system. Results: All animals included in the study had blood glucose above $250 \mathrm{mg} / \mathrm{dL}$ on the second day after streptozotocin administration and remained with high blood glucose until the 10th day, when the study was completed. After quantitative evaluation of collagen fibers, fibroblasts, vascular neoformation and macrophages performed in the ImagePro Plus 6.0 software, it was observed that the wound scores of diabetic animals treated with hyaluronic acid $(185 \pm 15.7)$ were significantly higher than 
those treated with saline $(134 \pm 11.7)$. The difference was statistically significant ( $p$ $<0.05)$. Conclusion: Treatment of open wounds with HA effectively improved the healing process in hyperglycemic rats through an anti-inflammatory effect. This study suggests and provided evidence that topical use of HA is promising in the treatment of wounds in diabetic rats.

Keywords: Wound healing. Diabetes. Hyaluronic acid. Treatment. Animal model. Rats.

\section{RESUMO}

Objetivo: O objetivo deste estudo foi examinar o efeito do tratamento tópico com ácido hialurônico $(\mathrm{AH})$ na cicatrização de feridas em ratos diabéticos. Métodos: Ratos Wistar pesando $279 \pm 32 \mathrm{~g}$ foram selecionados aleatoriamente e alocados em 2 grupos, com seis ratos cada, todos submetidos à indução de diabetes com estreptozotocina. Sob anestesia, foi feita uma ferida aberta de $1 \mathrm{~cm} 2$ na pele dorsal de todos os animais. Grupo 1 - ratos tratados com soro fisiológico a 0,9\% em feridas abertas na pele. Grupo 2 - ratos tratados com uso tópico de HA de $0,4 \%$ sobre lesões cutâneas. Após anestesia no 10 은 dia de pós-operatório, foi realizada biópsia da área dorsal da pele, incluindo toda a ferida cicatrizante, para exame histopatológico. A análise quantitativa foi realizada para a quantidade de macrófagos, neoformação vascular, fibroblastos e fibras de colágeno, utilizando um sistema de digitalizador e analisador de imagens. Resultados: Todos os animais incluídos no estudo apresentaram glicemia acima de $250 \mathrm{mg} / \mathrm{dL}$ no segundo dia após a administração de estreptozotocina e permaneceram com glicemia alta até o décimo dia, quando o estudo foi concluído. Após avaliação quantitativa das fibras colágenas, fibroblastos, neoformação vascular e macrófagos realizados no software ImagePro Plus 6.0, observou-se que os escores de feridas em animais diabéticos tratados com ácido hialurônico $(185 \pm 15,7)$ foram significativamente maiores do que os tratados com solução salina $(134 \pm 11,7)$. A diferença foi estatisticamente significante ( $p$ $<0,05)$. Conclusão: $\mathrm{O}$ tratamento de feridas abertas com AH melhorou efetivamente $\mathrm{O}$ processo de cicatrização em ratos hiperglicêmicos através de um efeito antiinflamatório. Este estudo sugere e fornece evidências de que o uso tópico de HA é promissor no tratamento de feridas em ratos diabéticos.

Descritores: Cicatrização de feridas. Ácido hialurônico. Tratamento. Modelo animal. Ratos. 


\section{INTRODUCTION}

Diabetes, which affects about $8 \%$ of the population ${ }^{1}$, is a disease in which abnormal glucose metabolism plays a central role. Hyperglycemia (defined as high blood glucose levels) results from the loss of pancreatic insulin-producing beta cells in type 1 diabetes, or loss of normal insulin response from target cells such as muscle and fat cells in type 2 diabetes, and leads to serious clinical complications over time ${ }^{2}$. These complications include renal failure, retinopathy, atherosclerosis, peripheral vascular disease, loss of peripheral sensory nerve function (neuropathy) and impairment of wound healing capacity. The combined effects of neuropathy and poor wound healing lead to the formation of non-healing skin ulcers in the feet and lower limbs, a particularly common problem in diabetics ${ }^{3}$. Almost $15 \%$ of diabetic individuals develop a foot ulcer, and many eventually lose a limb for amputation, with a very high cost to the public health system ${ }^{3}$. Evidence suggests that impaired wound healing in diabetic patients is directly related to poorly regulated serum glucose levels ${ }^{3}$. For example, an important clinical study in diabetics showed that high levels of hemoglobin A1c, an indicator of poor hyperglycemic control, correlated directly with delayed healing ${ }^{4}$. Unfortunately, despite improved methods of adequate insulin supply and glucose control, unhealed wounds and chronic ulcers remain a persistent problem.

Hyaluronic acid (HA) is a glycosaminoglycan (GAG), present in all mammalian tissues, composed entirely of two sugar subunits, glucuronic acid and $\mathrm{N}$ acetylglycosamine ${ }^{5}$. Very abundant in skin and many other tissues, HA is structurally simple but functionally complex ${ }^{6}$. Evidence is that deficiencies in wound healing in diabetics are mechanically linked to hyperglycemia through HA synthesis and degradation. Indeed, hyperglycemia leads to degradation of HA in the pericellular lining of endothelial cells, thereby increasing leukocyte recruitment and creating a proinflammatory microenvironment that adversely affects not only blood vessel function, but also adjacent pericytes, smooth muscle cells, and fibroblasts. . Inflammation and fibrosis (scar formation) are prominent features during normal wound healing ${ }^{7}$. Wound healing is a very complex process involving three overlapping phases 
that make up: the inflammatory phase, (days 1 to 3 ); tissue regenerative or proliferative phase ( 3 days 3 to 10$)$; and remodeling phase, ( 2 weeks to 3 months $)^{8,9}$.

Fibroblasts are the cells that produce most of the collagen and other matrix molecules that make up the new extracellular matrix (ECM). Scar tissue is gradually remodeled over many months, approaching but never reproducing the original architecture; thus, healed adult wounds typically reach only $70 \%$ of the initial rupture force on traction of the skin or other organ. The general sequence of events during wound healing implies that inflammation and fibrosis are closely linked. Excessive or prolonged presence of inflammatory cells in a wound will cause myofibroblast conversion, increase fibrosis (with imperfect macromolecular assembly of collagen and glycosaminoglycan elements (GAGs) and result in functionally compromised scar tissue.

In diabetes, wound healing is delayed ${ }^{10}$. The main reason for this seems to be chronic and increased inflammation, which disrupts ECM synthesis time and ultimately reduces the quality of the restored collagen architecture. Diabetic patients with poor hyperglycemic control appear to be in a high inflammatory state, even in the absence of injury or infection. This important concept was demonstrated by a clinical study in which 108 diabetic patients and 36 healthy controls were prospectively followed for 2 years ${ }^{11}$. At baseline, patients were free of ulcer, but foot ulcers developed in almost one third (29\%) of diabetic patients over time. In the first consultation of the study, all patients underwent blood collection and skin biopsy to measure serum protein markers and skin histopathology. Notably, the levels of many inflammation-associated cytokines and proteins (interleukins IL-6 and IL-8, tumor necrosis factor alpha, TNF- $\alpha$, C-reactive protein, fibrinogen) were significantly elevated in diabetic patients at baseline. In forearm (non-injured) skin biopsies, diabetics had a larger number of cells in general, and the number of inflammatory cells around the blood vessels (a strong indicator of inflammation) was higher. These findings suggest a pre-existing hyperinflammatory state. Experimental studies in diabetic animal models, including mice ${ }^{12}$ and rabbits ${ }^{13}$, also clearly demonstrated baseline increases in inflammatory cytokines (IL-6, IL-8 and TNF- $\alpha$ ) in diabetic skin in the absence of injury. This chronic proinflammatory state in diabetic skin may be caused by underlying abnormalities in HA and other GAGs that form the pericellular matrix on the apical surfaces of endothelial cells. The pericellular matrix 
(glycocalyx) is a structure comprising HA and various GAG-containing proteoglycans that is present to varying degrees in most cell types ${ }^{14}$.

Therefore, there is currently evidence on the mechanisms by which altered $\mathrm{HA}$ in tissue microvessels can lead to poor healing in diabetic patients. The main premise is that hyperglycemia causes loss of HA-containing glycocalyx on microvessel endothelial surfaces, leading to increased leukocyte adhesion and triggering the release of cytokines that contribute to a pro-inflammatory environment. Such changes are likely to increase oxidative damage, decrease adequate vascular endothelial cell response, and prevent /neoangiogenesis and other repair responses during the tissue regenerative phase of wound healing. Other types of blood vessel wall cells, including pericytes, smooth muscle cells, and fibroblasts, are also adversely affected by hyperglycemia and cytokines. this microenvironment through different mechanisms ${ }^{15}$.

In this context, the objective of this study is to examine the effect of topical HA treatment on wound healing in diabetic rats.

\section{METHODS}

Wistar rats, 3 to 4 months old weighing $279 \pm 32 \mathrm{~g}$, from the Biotery of the Health Sciences Center of the Federal University of Rio Grande do Norte were used. This protocol was submitted for approval by the Ethics Committee for Animal Use (CEUAHUOL) and approved with opinion number 07/2018. Wistar rats were kept in individual polypropylene cages with 12 hours light-dark cycles. Initially, the animals underwent a 7-day acclimatization period at the UFRN experimental surgery laboratory, with ad libitum access to water and rat food (Presence ${ }^{\bullet}$ ). Care in the use of animals followed the rules in force in the Brazilian Legislation for the scientific use of animals (Law No. 11.794 / 2008).

The animals were randomly selected and allocated into 2 groups, with six rats each, all submitted to streptozotocin-induced diabetes. Group 1 - rats treated with topical $0.9 \%$ saline application on open skin wounds. Group 2 - rats treated with topical application of HA on skin lesions.

\section{Diabetes induction}


Rats were treated with a single dose of streptozotocin (STZ) (Sigma-Aldrich ${ }^{\circledR}$ ) (50 $\mathrm{mg} / \mathrm{kg}$ dissolved in $\mathrm{pH} 4.5$ buffered citrate) to induce diabetes. With this dose the beta cells were destroyed and theoretically it was created an insulin-dependent diabetes model. About 48 hours after STZ use, blood glucose was measured by hand glucometer (Accu-chek, Roche ${ }^{\circledR}$, Germany). The study included only animals with blood glucose levels above $250 \mathrm{mg} / \mathrm{dL}$.

\section{Surgical procedures}

To perform the surgical procedure, the rats were anesthetized with intraperitoneal ketamine (i.p.) $70 \mathrm{mg} / \mathrm{kg}$ weight, combined with xylazine at a dose of 7 $\mathrm{mg} / \mathrm{kg}$ weight and operated under aseptic technique. After epilation of the back skin and antisepsis of the dorsal skin with $70 \%$ alcohol, a $1 \mathrm{~cm}$ diameter full circular open skin wound was made in each animal. After the operations, postoperative pain was controlled with analgesia (i.m. meperidine at a dose of $10 \mathrm{mg} / \mathrm{kg}$, a daily dose for the first 3 days). The animals received a solid rodent diet until the 10th day of observation. The animals were weighed before the operation and in the immediate moment before euthanasia, which occurred on the 10th day of observation. The animals were manipulated in the operating room of the Experimental Surgery Center - UFRN and during the observation period were kept in the postoperative control room of the same Center.

\section{Wound Care}

The wounds remained open for second intention healing and received the following treatments:

$0.9 \%$ saline group (control): daily topical treatment with 02 drops of $0.9 \%$ saline for 10 days.

Group $\mathrm{AH}$ : daily topical treatment with 02 drops of $0.4 \% \mathrm{HA}$ for 10 days.

\section{Evaluation of skin healing}

After anesthesia on the 10th postoperative day, a biopsy of the skin dorsal wound area, including the entire healing wound, was performed for histopathological 
examination. Euthanasia of the animals was then performed with anesthetic overdose (thiopental $100 \mathrm{mg} / \mathrm{kg}$ i.p.).

The skin sample was taken and fixed in $10 \%$ buffered formalin and embedded in paraffin. $5 \mu \mathrm{m}$ sections were stained with hematoxylin / eosin and analyzed by optical microscopy by experienced pathologist, without prior knowledge of the respective groups. Quantitative analysis was performed for the amount of macrophages, vascular neoformation, fibroblasts and collagen fibers, using a digitizer and image analyzer system. The total area of the microscopic fields was observed under an optical microscope (Olympus BX50), whose image was captured by an Olympus high resolution camera and analyzed using ImagePro-plus Software (Media Cybernetics-LP, USA). Each digitized field was quantified in pixel units with defined coordinates, and five random microscopic fields per slide were evaluated. After selecting the desired resolution, the images were stored to quantify the density of cells and collagen fibers.

\section{Statistics}

Statistical evaluation was performed using BioEstat 5.0 software through analysis of variance (ANOVA), followed by Student's t-test, considering significant differences when $p<0.05$.

\section{RESULTS}

\section{Blood glucose determination}

All animals included in the study had blood glucose levels above $250 \mathrm{mg} / \mathrm{dL}$ on the second day after streptozotocin administration and remained on high blood glucose until day 10th when the study was completed. Blood glucose data are summarized in table 1.

Table 1 - Measurement of blood glucose in the $2^{\text {nd }}$ day and $10^{\text {th }}$ day after STZ injection in rats of the study groups.

\begin{tabular}{ccc}
\hline \multirow{2}{*}{ Day } & \multicolumn{2}{c}{ Group } \\
\cline { 2 - 3 } & DIAB/NS & DIAB/AH \\
\hline $2^{\text {nd }} \mathrm{DAY}(\mathrm{mg} / \mathrm{dL})$ & $385.2 \pm 10.7^{\text {a }}$ & $396.4 \pm 16.7^{\text {a }}$ \\
$10^{\text {th }} \mathrm{DAY}(\mathrm{mg} / \mathrm{dL})$ & $288.6 \pm 17.2^{\text {a }}$ & $297.8 \pm 15.3^{\text {a }}$ \\
\hline
\end{tabular}

DIAB, diabetes; NS, normal saline; HA, hyaluronic acid. Values followed by the same letter on the same column differ significantly $(p<0.05$, Tukey test). 


\section{Histopathology}

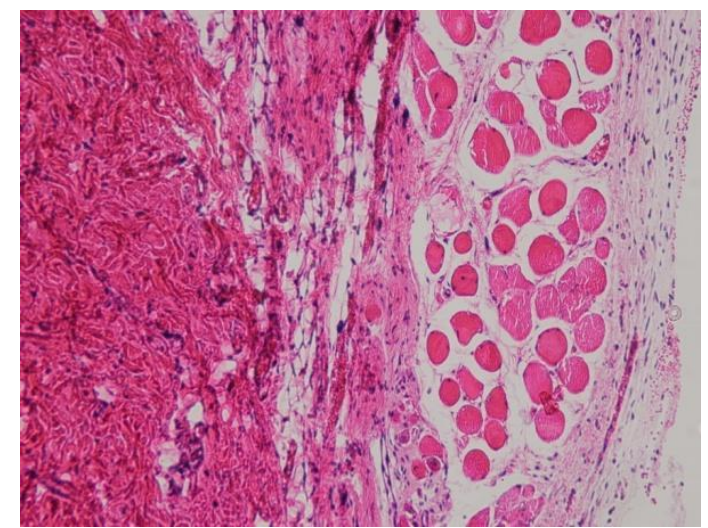

A

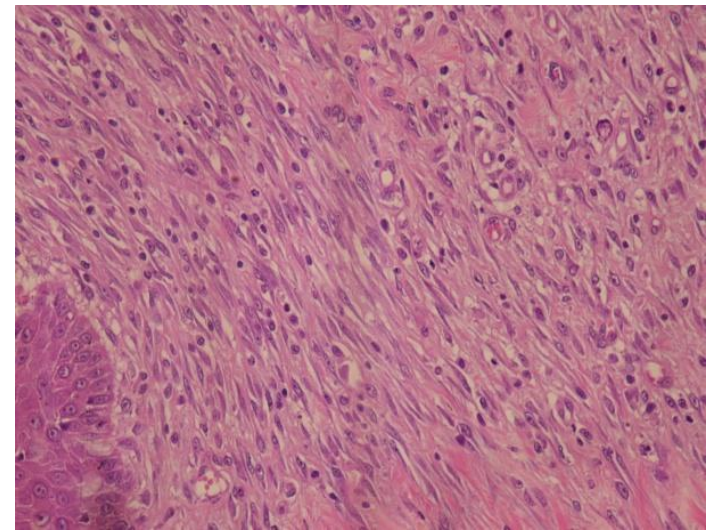

B

Figure 1 - Representative figures of skin healing of the two study groups on the 10th postoperative day. A, control group: areas of inflammatory foci, rare fibroblasts, rare collagen fibers. B, group Hyaluronic acid: a large number of cells with elongated nuclei (fibroblasts |), and a large number of collagen fibers.

After quantitative evaluation of collagen fibers, fibroblasts, vascular neoformation and macrophages performed in the ImagePro Plus 6.0 software, it was observed that the wound scores of diabetic animals treated with hyaluronic acid (185 \pm 15.7) were significantly higher than those treated with diabetics. with saline (134 \pm 11.7$)$; (table 2). The difference was significant $(p<0.05)$. These data are summarized in table 2. Morphological aspects of histopathology can be observed in figure 1.

Table 2 - Histological score values in the wounds of rats of the respective groups on the 10 th day of observation. (Measured using ImagePro 6.0 software).

\begin{tabular}{|c|c|}
\hline Groups & Scores \\
\hline DIAB/NS & $134 \pm 11.7^{a}$ \\
\hline DIAB/HA & $185 \pm 15.7^{a}$ \\
\hline
\end{tabular}

DIAB, Diabetes; NS, normal saline; HA, hyaluronic acid. Measurements followed by the same letter in the same column differ significantly ( $p<0.05$, Student's t-test).

\section{DISCUSSION}

Impaired wound healing represents one of the main diabetic complications in clinical practice. In general, hyperglycemia causes changes in endothelial cell function and, consequently, vascular dysfunction in the wounds, which become infected and, in many cases, lead to amputations ${ }^{15}$. Changes in several endogenous factors are known to contribute to delayed healing, including low growth factor production, mediators 
involved in angiogenic response, macrophage function, collagen synthesis, epidermal barrier function, keratinocyte migration, and fibroblast proliferation ${ }^{16,17}$.

The healing process has been documented in animal models, and excision wound models have become effective preclinical testing methods in diabetic rat studies ${ }^{18}$. Rodents are commonly used as a model for wound healing. However, the mechanics of wound healing vary between rodents and humans. In humans, wound healing mainly depends on keratinocyte growth and migration in the epidermis and formation of granulation tissue in the dermis, while wound contraction is more important during rodent wound closure. This is because rodents have a subcutaneous fleshy paniculus muscle that facilitates skin healing through both wound contraction and collagen formation ${ }^{19}$. However, human wounds depend on the contractile properties of dermal myofibroblasts, especially during the remodeling phase of healing ${ }^{20}$.

Measuring blood glucose levels is one of the most effective diagnostic methods in monitoring diabetes. Thus, glycemic assessment was chosen as the main parameter for disease progression in this study. In our study a single injection of streptozotocin (STZ) was able to significantly increase fasting rat glucose. This is because STZ is a diabetogenic agent, inducing necrosis by damaging pancreatic $\beta$ cell DNA ${ }^{21}$, with an effective decrease in insulin production, which eventually generates a diabetic phenotype. In the present study, all animals after STZ injection maintained blood glucose above $250 \mathrm{mg} / \mathrm{dL}$, even after any of the topical treatments, suggesting that HA did not interfere with the animals' blood glucose levels throughout the experimental period. In our study, characteristic signs were noted from the second day of administration of STZ.

We demonstrated in the present study an important role of HA in wound healing in streptozotocin-induced hyperglycemic rats. In addition, we observed histologically better granulation tissue formation with marked fibroblast proliferation, increased vascularization and deposition of collagen fibers after HA treatment. The results suggest better and accelerated healing in hyperglycemic rats treated with HA.

HA plays several roles in healing. Although inflammation is crucial for granulation tissue formation, stabilization of the granulation tissue matrix is required, relieving inflammation to maintain normal tissue repair. The role of free radical scavenging by HA may influence inflammatory activation. In this sense, HA provides 
protection against free radical and proteolytic damage to cells and extracellular matrix (ECM)22. Campo et al. ${ }^{23}$ showed that HA reduced inflammatory mediators, such as tumor necrosis factor $\alpha, I L-1 \beta, I L-17, M M P-13$ and induced nitric oxide synthesis, which play active roles in inflammation. HA is one of the main components of MEC. It is the most important support structure of proteoglycans. It is also associated with collagen, fibrin and other matrix molecules. HA promotes early response to tissue damage and fibrin-rich matrix formation. Consequently, it promotes the movement of fibroblasts and endothelial cells to the wound area and subsequent formation of granulation tissue in the early phase of tissue repair. When HA binds to ECM components through its hydrophilic structure, it creates an environment that allows cell migration to the newly formed tissue region ${ }^{24}$. Successful therapy would require a drug that would accelerate wound healing with potential involvement at all stages of the process, with low cost and minor side effects. The findings of the present study showed that HA was effective in promoting wound healing in hyperglycemic rats, reducing the size of the lesion on day 10 , accompanied by wound contraction.

The quality of wound healing depends on the formation of granulation tissue that is directly affected in diabetics. An increase in granulation tissue formation requires an increase in cell proliferation of fibroblasts and endothelial cells and a consequent increase in collagen synthesis ${ }^{25,26}$. Collagen is well documented as one of the major and most important components of granulation tissue, and its synthesis occurs in fibroblasts, which is dependent on TGF- $\beta 1$, a crucial factor for proper wound healing ${ }^{27}$. The role of HA in the proliferative phase was validated in this study through histopathological study, where it was possible to observe an increase in fibroblast proliferation in the central region of the wounds, an increase in the formation of collagen fibers at both the edges and the center of the lesion. Overall, the study demonstrated through an excisional wound model in streptozotocin-induced hyperglycemic rats that topical application of HA accelerates the healing of skin wounds promoting anti-inflammatory effects, neovascularization, and improved granulation tissue formation.

In conclusion, the treatment of open wounds with HA positively influenced the healing process in hyperglycemic rats. Histopathological findings revealed a decrease in the inflammatory process, neovasculogenesis and more intense proliferation of 
fibroblasts in the HA group. This study suggests and provided evidence that HA application is promising in wound healing in hyperglycemic rats. The present study may have clinical implications, as HA may be useful for the treatment of delayed healing wounds in cases of diabetes.

\section{REFERENCES}

1. Cowie C C, Rust K F, Ford E S, et al. Full accounting of diabetes and pre-diabetes in the U.S. population in 1988-1994 and 2005-2006, Diab Care. 2009; 32: 287-94.

2. Nathan D M, Zinman B, Cleary P A. et al. Modern-day clinical course of type 1 diabetes mellitus after 30 years' duration: the diabetes control and complications trial/epidemiology of diabetes interventions and complications and Pittsburgh epidemiology of diabetes complications experience (1983-2005). Arch Int Med. 2009;169: 1307-16.

3. Gordois A, Scuffham P, Shearer A, Oglesby A. Tobian J A. The health care costs of diabetic peripheral neuropathy in the U.S. Diab Care. 2003; 26:1790-5.

4. Christman A L, Selvin E, Margolis D J, Lazarus G S, Garza L A. Hemoglobin A1C predicts healing rate in diabetic wounds. J Invest Dermatol. 2011; 131:2121-7.

5. Ghose S, Biswas S, Datta K, Tyagi RK. Dynamic Hyaluronan drives liver endothelial cells towards angiogenesis. BMC Cancer. 2018;18:648.

6. Tammi M I, Day A J, Turley E A. Hyaluronan and homeostasis: a balancing act. J Biol Chem. 2002; 277:4581-4.

7. Ghatak S, Maytin S, Mack EV, Hascall JA, Atanelishvili VC, Moreno Rodriguez I, Markwald R, Misra RR. Roles of proteoglycans and glycosaminoglycans in wound healing and fibrosis. Int J Cell Biol. 2015;2015:834-93.

8. Raffetto JD. Pathophysiology of wound healing and alterations in venous leg ulcersreview. Phlebology. 2016;31(1Suppl):56-62.

9. Johnson TR, Gómez BI, Mclntyre MK, Dubick MA, Christy RJ, Nicholson $\mathrm{SE}$,Burmeister DM. The cutaneous microbiome and wounds: new molecular targets to promote wound healing. Int J Mol Sci. 2018;19):E2699.

10. Velander $\mathrm{P}$, Theopold $\mathrm{C}$, Hirsch $\mathrm{T}$, et al. Impaired wound healing in an acute diabetic pig model and the effects of local hyperglycemia. Wound Repair Regen. 2008;16:288-93.

11. Dinh T, Tecilazich F, Kafanas A, et al. Mechanisms involved in the development and healing of diabetic foot ulceration. Diabetes. 2012; 61:2937-47.

12. Algenstaedt $P$, Schaefer $C$, Biermann $T$, et al. Microvascular alterations in diabetic mice correlate with level of hyperglycemia. Diabetes. 2003; 52:542-9.

13. Pradhan L, Cai X, Wu S, et al. Gene expression of proinflammatory cytokines and neuropeptides in diabetic wound healing. J Surg Res. 2011;167:336-42. 
14. Frati Munari AC. Medical significance of endothelial glycocalyx. Part 2: Its role in vascular diseases and in diabetic complications. Arch Cardiol Mex. 2014;84:110-6.

15. Blakytny R., Jude E. The molecular biology of chronic wounds and delayed healing in diabetes. Diab Med. 2006;23:594-608.

16. Maruyama K, Asai J, li M, Thorne T, Losordo D W, D'Amore P A. Decreased macrophage number and activation lead to reduced lymphatic vessel formation and contribute to impaired diabetic wound healing. Am J Pathol. 2007;170:1178-91.

17. Galiano R D, Tepper O M, Pelo C R, et al. Topical vascular endothelial growth factor accelerates diabetic wound healing through increased angiogenesis and by mobilizing and recruiting bone marrow-derived cells. Am J Pathol. 2004;164:193547.

18. Scherer S S, Pietramaggiori G, Mathews J C, Chan R, Fiorina P, Orgill D. P. Wound healing kinetics of the genetically diabetic mouse. Wounds. 2008;20:18-28.

19. Dorsett-Martin W A. Rat models of skin wound healing: a review. Wound Repair Regen. 2004;12:591-9.

20. Levinson $\mathrm{H}$. A paradigm of fibroblast activation and dermal wound contraction to guide the development of therapies for chronic wounds and pathologic scars. Adv Wound Care. 2013;2:149-59.

21. Szkudelski T. The mechanism of alloxan and streptozotocin action in B cells of the rat pancreas. Physiol Res. 2001;50:537-46.

22. Foschi D, Castoldi L, Radaelli E, Abelli P, Calderini G, Rastrelli A, Mariscotti C, Marazzi $M$, Trabucchi E. Hyaluronic acid prevents oxygen free-radical damage to granulation tissue: a study in rats. Int J Tissue React. 1990;6:333-9.

23. Campo GM1, Avenoso A, Nastasi G, Micali A, Prestipino V, Vaccaro M, D'Ascola A, Calatroni A, Campo S. Hyaluronan reduces inflammation in experimental arthritis by modulating TLR-2 and TLR-4 cartilage expression. Biochim Biophys Acta. 2011;9:1170-81.

24. Tolg C, Telmer P, Turley E. Specific sizes of hyaluronan oligosaccharides stimulate fibroblast migration and excisional wound repair. PLoS One. 2014;9(2):e88479.

25. Fikru A, Makonnen E, Eguale T, Debella A, Abie Mekonnen G. Evaluation of in vivo wound healing activity of methanol extract of Achyranthes aspera L.J Ethnopharmacol. 2012;143:469-74.

26. Chen J, Kasper $M$, Heck $T$, et al. Tissue factor as a link between wounding and tissue repair. Diabetes. 2005;54:2143-54.

27. Brem H, Kodra A, Golinko M S, et al. Mechanism of sustained release of vascular endothelial growth factor in accelerating experimental diabetic healing. J Invest Dermatol. 2009;129:2275-87. 